\title{
RELATIONSHIP BETWEEN WORK AND ANXIETY OF PRIMIGRAVIDA PREGNANT WOMEN IN TRIMESTER III IN FACING CHILDBIRTH AT BATU AJI COMMUNITY HEALTH CENTER
}

\author{
Fitta Deskawaty $^{1}$, Roni Aldiano ${ }^{2}$ \\ fittadeskawaty@ univbatam.ac.id ${ }^{1}$, ronialdiano@univbatam.ac.id ${ }^{2}$ \\ Medical Education Study Program, Faculty of Medicine, Batam University \\ Doctor's Professional Study Program, Faculty of Medicine, Batam University \\ Jl. Uniba No. 5, Batam Center
}

\begin{abstract}
Background : Suyati et al (2011) conducted a study on the relationship between knowledge of pregnant women about the delivery process and the level of anxiety in facing childbirth. It was found that out of 48 pregnant women, 13 pregnant women $(27.1 \%)$ had sufficient knowledge and experienced severe anxiety. This is because the understanding of a pregnant woman to know the process of childbirth is very important because pregnant women often have disturbing thoughts, as a development of an anxiety reaction to the stories they get. A number of fears arise in the third trimester. Pregnant women will feel anxious about the life of the baby and his own life, such as: whether the baby will be born normally. The purpose of this study is the relationship between work and the anxiety of primigravida pregnant women trimester III in dealing with childbirth.
\end{abstract}

Method : The design in this study was cross sectional. The research was carried out at Puskesmas Batu Aji. The population in this study were all trimester III primigravida pregnant women who visited and performed ANC examinations. The sampling technique used in this study was total sampling. The instrument in this study used a questionnaire sheet and a check list. To measure the level of anxiety using the Hamilton Rating Scale for Anxiety (HRS-A). Chi-Square hypothesis test.

Result : Research Results From the results of the chi-square calculation, the p-value is 0.571 , which means that the $p$-value is $\geq 0.05$.

Conclusion : The conclusion is that there is a relationship between work and the anxiety of primigravida pregnant women trimester III in dealing with childbirth

Keywords: Occupation, Basic Immunization, Infants

\section{INTRODUCTION}

WHO estimates that in Indonesia there are 126 maternal deaths per 100,000 live births with a total number of maternal deaths of 6400 in 2015. This figure has decreased from the 2012 IDHS, which is 359 per 100,000 live births (Yunin, 2015).

Maternal Mortality Rate (MMR) is an indicator used to measure maternal health status in an area. Maternal death is death during pregnancy or within a period of 42 days after pregnancy due to all causes related to or aggravated by pregnancy or its handling, but not caused by accident or injury (Yunin, 2015). The Maternal Mortality Rate (MMR) in Indonesia has decreased from 4,999 in 2015 to 4912 in
2016 and in 2017 (first semester) as many as 1712 cases (Depkes RI, 2017).

The low level of public awareness about the health of pregnant women is a determining factor in the mortality rate, although there are still many factors that must be considered in dealing with this problem. The issue of death that occurs is due to common indications, namely bleeding, pregnancy poisoning accompanied by convulsions, abortion, and infection (Depkes RI, 2015)

Normal delivery is a labor that takes place with the mother's own strength without the aid of tools and does not injure the mother and her fetus. Stage II labor begins when the cervix is fully dilated and ends when the fetus is born. The 
stages or stages of labor include stage I (when opening), stage II (time of expulsion), stage III (time of uri), stage IV (during observation or supervision). In stage II primigravidas labor usually lasts $<1$ hour, whereas in multigravidas it usually lasts $<30$ minutes. The factors that influence childbirth include the power or strength of the mother (power), the fetus (passanger), the birth canal (passage), the psyche (psyche) including anxiety. Anxiety in laboring mothers will affect the delivery process (Sagita, 2017).

Danuatmaja and Meiliasari stated that anxiety and fear can cause intense pain and can also lead to decreased uterine contractions, so that labor will take longer. Research shows that labor pain, especially when I first stage is more felt in primigravidas, amounting to $59.38 \%$, while in multigravidas it is $40.62 \%$ (Difarissa, 2015)

Anxiety is normal for all humans, but anxiety becomes abnormal when a person responds to anxiety unrealistically / excessively and results in physical, psychological, and social disorders. Anxiety is an emotion that has long been associated with pregnancy, the relationship of which is unclear. Anxiety may be a positive emotion as a protection against stressors, which can become a problem if it is excessive (Pieter, et al, 2011).

Anxiety or anxiety is part of an emotional response, where anxiety is an unclear and pervasive worry related to feelings of uncertainty and helplessness. This emotional state has no specific object. Where anxiety is experienced interpersonal. An individual who experiences anxiety can directly express anxiety through physiological and behavioral responses (Stuart, 2006). This anxiety can be experienced by mothers during pregnancy, especially in the final trimester of pregnancy before delivery (Wahyuningsih, 2015). The concerns felt by pregnant women in the first, second, and third trimesters have their own characteristics according to problems in their pregnancy (Sulistiowati, 2013).Kecemasan dalam menghadai persalinan dikarenakan oleh beberapa faktor salah satunya adalah pekerjaan. Pekrjaan ibu hamil dapat mempengaruhi kecemasan ibu, bahwa bekerja umumnya adalah kegiatan yang menyita waktu sehingga ibu hamil yang bekerja mengalami kecemasan lebih ringan dibandingkan ibu yang tidak bekerja dikarenakan pekerjaan dapat mengalihkan perasaan cemas ibu (Notoatmodjo, 2010).

The level of education of the mother can also affect the anxiety experienced by pregnant women, because the higher the level of individual education, the higher the level of knowledge obtained so that it is easier to receive information, especially in matters relating to health and this will affect the individual's behavior. Third trimester pregnant women with low or high education have the same opportunity to experience anxiety in the face of childbirth, because the anxiety that occurs does not only depend on their education but also depends on knowledge, interpersonal relationships, and family (Notoatmodjo, 2010).

The final trimester of pregnancy or the third trimester is often called the period of vigilance. Anxiety and fear of childbirth and childbirth increases so that it must be explained clearly about the labor and birth process so that the mother's confidence that she can go through the labor process should be clear. Anxiety in mothers arises from a lack of knowledge and unclear problems (Wahyuningsih, 2015).

Fear before childbirth is often experienced by mothers during pregnancy. This anxiety can be experienced by both primigravid and multiparous mothers. A primigravida mother is a woman who gives birth to a baby for the first time, while a multiparous woman is a woman who has given birth to a baby several times (Mochtar, 1988, in Susilowati 2012).

The first pregnancy is a very important one for women compared to the second, third, or so on. The first pregnancy is usually a lot of worry, fear, mixed anxiety and happiness. Pregnant women are worried about their pregnancy, when they are born, and how tired they are. Also happy when neighbors and friends give congratulations and prayers for her pregnancy (Al-Atiq, 2007).

From the research conducted by Handayani (2012), on "Factors Related to Anxiety Levels Toward Delivery in Third Trimester Primigravida Mothers in the Work Area of Puskesmas Lubuk Buaya Padang in 2012" it was found that the relationship between age, husband's support, and support family is very influential on the anxiety of primigravida third trimester pregnant women in dealing with their care. 
One of the factors' ability to respond to anxiety is age. Age maturity in the thought process of adults who are more likely to use good coping mechanisms than younger individuals. The husband's support that is received by the mother can reduce the level of anxiety in the mother, on the other hand, if the husband's support is lacking, it will cause anxiety in the mother. The moral and material support that will be provided by family members to realize a plan is something that can provide emotional benefits or influence a person's behavior. Having good family support, pregnant women can maintain their psychological condition and are more receptive to physical changes and control the emotional turmoil that arises.

Research conducted by Sagita (2017) on the relationship between anxiety levels and stage II delivery of mothers at the Hospital Anugerah Medical Center, Metro City found that the anxiety level of mothers who gave birth mostly experienced moderate levels of anxiety, as many as 17 out of 50 pregnant women (34\%) with the abnormal duration of the second stage of labor as many as 22 mothers (44\%). There is a relationship between the level of anxiety and the second stage of labor in mothers who give birth.

Suyati et al (2011) conducted a study on the relationship between knowledge of pregnant women about the delivery process and the level of anxiety in facing childbirth. It was found that out of 48 pregnant women, 13 pregnant women $(27.1 \%)$ had sufficient knowledge and experienced severe anxiety. This is because the understanding of a pregnant woman to know the process of childbirth is very important because pregnant women often have disturbing thoughts, as a development of an anxiety reaction to the stories they get. A number of fears arise in the third trimester. Pregnant women will feel anxious about the life of the baby and his own life, such as: whether the baby will be born normally.

Research conducted by Rosa (2015) on the relationship between characteristics and the level of anxiety of third trimester mothers in dealing with childbirth at the maternity house in Palembang, it was found that 37 pregnant women with high risk age experienced moderate anxiety, amounting to $31(83.8 \%)$ mothers. Meanwhile, there were 13 mothers with no risk of experiencing moderate anxiety (54.2\%). The results of the statistical test showed that the $\mathrm{p}$ - value $=0.026$ was smaller than $\alpha=0.05$. This shows that there is a significant relationship between age and the level of anxiety of third trimester pregnant women in facing childbirth at the Citra Maternity Hospital, Palembang in 2015.

According to data from the Batam City Health Office in 2017, the highest number of K4 visits coverage was at Batu Aji Health Center with a total of 4073 pregnant women. (Batam City Health Profile, 2017).

The purpose of this study is the relationship between work and the anxiety of primigravida pregnant women trimester III in dealing with childbirth

\section{RESEARCH METHODS}

The design in this study was cross sectional. The research was carried out at Puskesmas Batu Aji. The population in this study were all trimester III primigravida pregnant women who visited and performed ANC examinations. The sampling technique used in this study was total sampling. The instrument in this study used a questionnaire sheet and a check list. To measure the level of anxiety using the Hamilton Rating Scale for Anxiety (HRS-A). To determine the level of anxiety in pregnant women in facing childbirth, a Likert scale is used which consists of components in negative questions. Almost never the score is 1 , sometimes the score is 2 , often the score is 3 , always the score is 4 .In the negative question component, the score is on the assessment almost never (HTP) 4, Sometimes Sometimes (K) 3, Often (SR) 2, Always (SL) 1. To categorize the level of anxiety of pregnant women in facing childbirth, it is said that the level of anxiety is 20-35, the level of anxiety is moderate 35-50, severe anxiety level 51-65, and panic 66- 80. Chi-Square hypothesis test with $2 \times 2$ table, the test used is the Chi-Square test if it meets the requirement

\section{RESEARCH RESULT}

The Incidence of Anxiety of Third Trimester Primigravida Pregnant Women in Facing Childbirth

It is known that in 40 trimester III primigravida pregnant women at Batu Aji Health Center, Batam City, 23 (57.7\%) pregnant women experienced mild anxiety, 13 (32.5\%) pregnant women experienced moderate anxiety, and 4 
(10\%) pregnant women experiencing severe anxiety

\section{Occupation of Primigravida Timester III Pregnant Women in Facing Childbirth}

It is known that in 40 trimester III primigravida pregnant women at Batu Aji Community Health Center, 32 (80\%) mothers do not work, while 8 (20\%) pregnant women work.

\section{Relationship between Work and Anxiety of Primigravida Pregnant Women in Trimester III}

It is known that $23(100 \%)$ pregnant women who experience mild anxiety, 18 (78.3\%) who do not work, and 5 (21.7\%) women who work. Pregnant women who experience moderate anxiety $13(100 \%)$, where the mothers who do not work as much as $10(76.9 \%)$, and mothers who work as much as $3(23.1 \%)$. Mothers who experience severe anxiety as much as $4(100 \%)$, where the mothers who do not work are 4 $(100 \%)$, and mothers who work are $0(0 \%)$. From the results of the chi-square calculation, the $\mathrm{p}$-value is 0.571 , which means that the $\mathrm{p}$ value is $\geq 0.05$ so that Ho is accepted, it can be concluded that there is no significant relationship between work and anxiety of primigravida pregnant women in timester III

\section{DISCUSSION}

From the results of statistical tests, the chisquare calculation obtained a p-value of 0.0571 , which means $p$-value $\geq 0.05$ so that $\mathrm{Ho}$ is accepted, it can be concluded that there is no significant relationship between work and anxiety of primigravida pregnant women in timester III. at Puskesmas Batu Aji, Batam City 2018.

Pregnant women who work and pregnant women who do not work are at risk of experiencing anxiety. There are several other factors that can cause anxiety, for example the level of activity and traumatic experiences (Mayasari, 2016). This is not in accordance with the statement of Notoatmodjo (2010), that work is generally a time-consuming activity so that pregnant women who work experience less anxiety than those who do not work because work can divert feelings of anxiety.

The results of this study are in line with the research conducted by Astria et al. In 2009 concerning "The Relationship between the
Characteristics of Pregnant Women in Trimester Iii and Anxiety in Facing Childbirth at the Polyclinic of Obstetrics and Gynecology Hospital X Jakarta" with the results of calculations using the Chi-Square test obtained $=$ 0.133 , where the $\mathrm{p}$ value> 0.05 , which means there is no significant relationship between work and anxiety in dealing with childbirth. This is because pregnant women who work and who do not work together have a good adaptation to the changes that occur during pregnancy, so that these changes do not really affect the mother's physical or psychological condition in facing childbirth. In addition, it may be supported by sufficient family socio-economic factors so that maternal health status is guaranteed. Pregnant women always check their pregnancies regularly, plan for delivery in health personnel, and make other preparations well.

Based on the research conducted, it can be concluded that mothers who do not work experience mild anxiety as much as $18(45 \%)$. This is because mothers who do not work or who become housewives seek more knowledge about the delivery process so that they reduce anxiety, such as attending classes for pregnant women, from other people's experiences, or from electronic media.

\section{CONCLUSION}

Occupation of third trimester primigravida pregnant women at Batu Aji Community Health Center is $32(80 \%)$ non-working mothers, 8 (20\%) working mothers

\section{SUGGESTION}

For Respondents

It is hoped that respondents, especially pregnant women, more often use the facilities or services provided by the government or other health workers to increase knowledge or insight about pregnancy so that they can prepare for pregnancy to delivery properly.

\section{BIBLIOGRAPHY}
AKI.
2015. http://storage.jak- stik.ac.id/ProdukHukum/MenPAN/inde x.php- option $=$ com_docman \&task $=d o c \_d o w n l$ oad\& gid $=290 \&$ Itemid $=111$. pdf diakses Pada tanggal 10 April 2018 
Aprillia, Y. 2011. Pentingnya Pendamping Persalinan. Jakarta: PT Gramedia Widia Sarana Indonesia

Cervone, D., dan Lawrence A. P. 2012). Kepribadian: Teori dan Penelitian. Jakarta: Salemba Humanika.

Depkes. 2017. http://www.depkes.go.id/article/view/17 081700004/-inilah-capaian-kinerjakemenkes-ri-tahun-2015--2017.html diakses Pada tanggal 10 April 2018

Handayani, Reska. 2012. Faktor-Faktor Yang Berhubungan Dengan Tingkat Kecemasan Menjelang Persalinan Pada Ibu Primigravida Trimester III di Wilayah Kerja Puskesmas Lubuk Buaya Padang Tahun 2012. STIKes Amanah Padang.

Hawari, Dadang. 2011. Manajemen Stress Cemas Dan Depresi. Jakarta : FKUI.

Hidayat, A,A,A. 2009. Metode Penelitian Kesehatan. Surabaya: Kelapa Pariwara

Jannah,Nurul. 2012. Buku Ajar Asuhan Kebidanan :kehamilan. Yogyakarta: CV Andi OF SET

Manuaba, Ida Bagus Gede. 2010. Ilmu Kebidanan, Penyakit Kandungan, KB untuk Pendidikan Bidan. Jakarta: EGC

Mochtar, R. 1998. Sinopsis Obstetri Jilid 1. Jakarta: EGC.

Mochtar, R. 2002. Sinopsis Obstetri. Jakarta: Buku Kedokteran EGC Jakarta.

Notoadmodjo, S. 2011. Metodelogi Penelitian Kesehatan. Jakarta: Rineka Cipta

Notoatmodjo, 2010. Metodologi Penelitian Kesehatan. Jakarta; PT Rineka Cipta

Notoatmodjo, Soekidjo., 2010. Promosi Kesehatan : Teori dan Aplikasi. Jakarta : Rineka Cipta

Prawirohardjo, Sarwono. 2002. Ilmu Kebidanan. Jakarta: Yayasan Bina Pustaka Sarwono Prawirohardjo

Rochman Kholillur. (2010). Kesehatan Mental.Purwokerto: Fajar Media Press.

Rosa, Yunilda. 2015. Hubungan Karakteristik Dengan Tingkat Kecemasan Ibu Trimester III Dalam Menghadapi Persalinan Di Rumah Bersalin Citra Palembang Tahun 2015. STIK Siti Khadijah palembang.

Rumaiah, S. (2003). Kecemasan Bagaimana Mengatasi Penyebabnya. Jakarta: Pustaka Populer Obor.
Rumengan, Jimmy, 2015. Metode Penelitian Dengan Menggunakan SPSS. Batam. Universitas Batam.

Sagita, Yona Desni. 2017. Hubungan Tingkat Kecemasan Dengan Lama Persalinan Kala II Pada Ibu Bersalin Di RSIA Anugerah Medical Center Kota Metro. STIkes Aisyah Pringsewu Lampung

Saifuddin, Abdul B. 2014. Buku Acuan Nasional Pelayanan Kesehatan Maternal dan Neonatal, Jakarta: Yayasan Bina Pustaka Sarwono Prawirohardjo.

Shodiqoh, dkk. 2014. Perbedaan Tingkat Kecemasan Dalam Menghadapi Persalinan Antara Primigravida dan Multigravida. Surabaya : FKM UA

Simanjuntak, Lasma. 2012. Tingkat Kecemasan Dan Koping Ibu Hamil yang Berlatar Belakang Pendidikan Medis Dan Non Medisdalam Menghadapi Persalinandi Kota Pematang Sianta. Universitas Sumatra Utara : Medan

Siswosudarmo, R., 2008. Obstetri Fisiologi. Yogyakarta: Pustaka Cendekia.

Stuart, G., W. 2007. Buku Saku Keperawatan Jiwa (Edisi 5). Jakarta : EGC

Sulistyawati, Ari. 2010. Asuhan Kebidanan Pada Masa Kehamilan. Jogjakarta : CV. Andi Offset.

Suliswati et al. 2005. Konsep Dasar Keperawatan Kesehatan Jiwa. Jakarta : EGC.

Sumarah. 2009. Perawatan Ibu Bersalin : asuhan Kebidanan pada Ibu Bersalin. Yogyakarta

Susilowati, Dewi. 2012. Pengaruh Dukungan Keluarga Dan Paritas Terhadap Kecemasan Ibu Hamil Trimester III Dalam Menghadapi Persalinan Di RB Harapan Bunda Surakarta. Universitas Sebelas Maret : Surakarta

Wahyuningsih, Istiqomah Risa. 2015. FaktorFaktor Yang Berhubungan Dengan Tingkat Kecemasan Ibu Dalam Menghadapi Persalinan Di Rb Hasanah Gemolong Sragen. Sekolah Tinggi Ilmu Kesehatan Aisyiyah Surakarta.

Winknjosastro, H., 2002. Ilmu Kebidanan. Jakarta: Yayasan Bina Pustaka Sarwono Prawirohardjo

Yunin, Qurratu A. 2015. Hubungan Faktor Resiko Anemia Dengan Kejadian Abortus spontan Di Rsup Dr. M. Djamil 
ZONA KEDOKTERAN - Vol. 10 No. 3 September 2020

Padang Tahun 2015. FKM UNAND.

Padang. 